\title{
Merkel Cell Carcinoma cT0 TNM Finding v8
}

National Cancer Institute

\section{Source}

National Cancer Institute. Merkel Cell Carcinoma cTO TNM Finding v8. NCI Thesaurus.

Code C136842.

Merkel cell carcinoma with no evidence of primary tumor. (from AJCC 8th Ed.) 